This document was prepared in conjunction with work accomplished under Contract No. DE-AC09-96SR18500 with the U. S. Department of Energy.

\title{
DISCLAIMER
}

This report was prepared as an account of work sponsored by an agency of the United States Government. Neither the United States Government nor any agency thereof, nor any of their employees, nor any of their contractors, subcontractors or their employees, makes any warranty, express or implied, or assumes any legal liability or responsibility for the accuracy, completeness, or any third party's use or the results of such use of any information, apparatus, product, or process disclosed, or represents that its use would not infringe privately owned rights. Reference herein to any specific commercial product, process, or service by trade name, trademark, manufacturer, or otherwise, does not necessarily constitute or imply its endorsement, recommendation, or favoring by the United States Government or any agency thereof or its contractors or subcontractors. The views and opinions of authors expressed herein do not necessarily state or reflect those of the United States Government or any agency thereof. 


\section{THE IMPACT OF THE SOURCE OF ALKALI ON SLUDGE BATCH 3 MELT RATE (U)}

M. E. Smith

D. H. Miller

T. M. Jones

April 2005

Immobilization Technology Section Savannah River National Laboratory

Aiken, SC 29808

Prepared for the U.S. Department of Energy Under Contract Number DEAC09-96SR18500

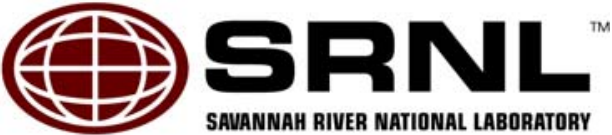

We Put Science To Work 


\title{
DISCLAIMER
}

This report was prepared by Westinghouse Savannah River Company (WSRC) for the United States Department of Energy under Contract No. DE-AC09-96SR18500 and is an account of work performed under that contract. Neither the United States Department of Energy, nor WSRC, nor any of their employees makes any warranty, expressed or implied, or assumes any legal liability or responsibility for the accuracy, completeness, or usefulness, of any information, apparatus, or product or process disclosed herein or represents that its use will not infringe privately owned rights. Reference herein to any specific commercial product, process, or service by trademark, name, manufacturer or otherwise does not necessarily constitute or imply endorsement, recommendation, or favoring of same by WSRC or by the United States Government or any agency thereof. The views and opinions of the authors expressed herein do not necessarily state or reflect those of the United States Government or any agency thereof.

\author{
Printed in the United States of America \\ Prepared For \\ U.S. Department of Energy
}


Key Words: Melt rate, alkali, DWPF, glass

Retention: Permanent

\section{THE IMPACT OF THE SOURCE OF ALKALI ON SLUDGE BATCH 3 MELT RATE (U)}

M. E. Smith

D. H. Miller

T. M. Jones

April 2005

Immobilization Technology Section Savannah River National Laboratory Aiken, SC 29808

Prepared for the U.S. Department of Energy Under Contract Number DEAC09-96SR18500

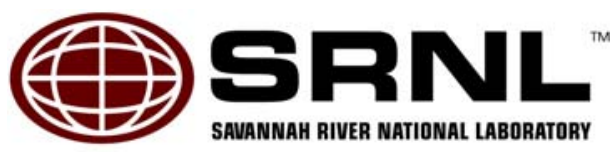

We Put Science To Work 


\section{REVIEWS AND APPROVALS}

\section{AUTHORS:}

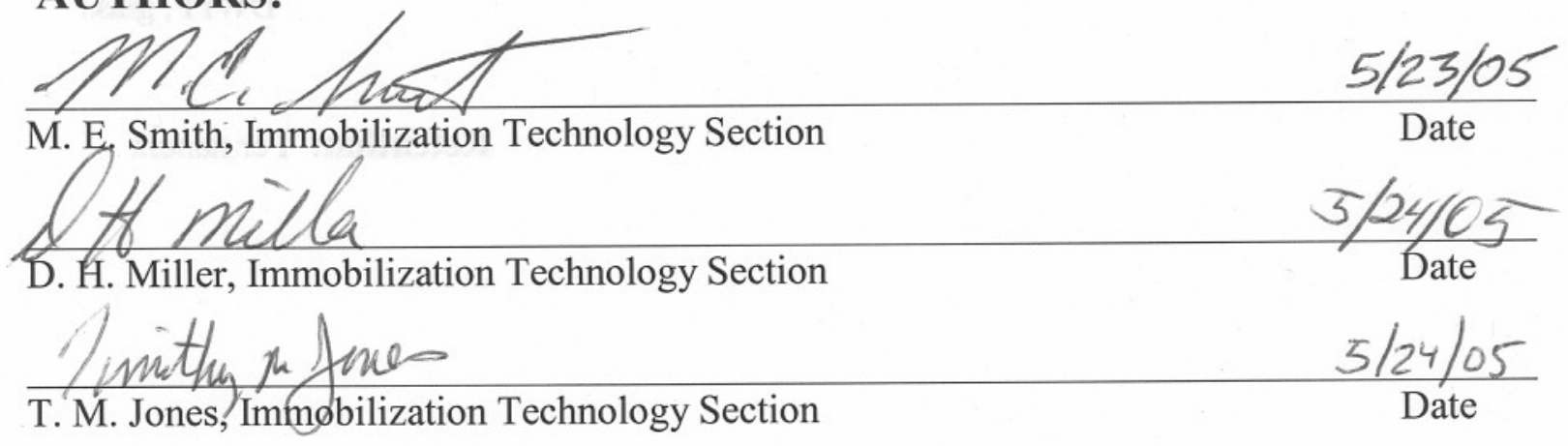

\section{TECHNICAL REVIEWER:}

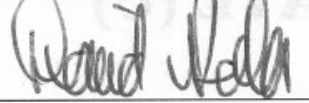

D. K. Peeler, Immobilization Technology Section

$5-2 y-05$

Date

\section{APPROVERS}

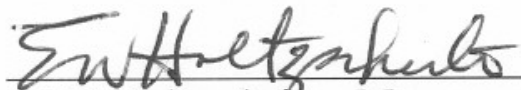

E. W. HoltzschePer, Manager, Immobilization Technology Section

Shaven fonama

S. L. Marra, Manager, Glass Formulation \& Process Development

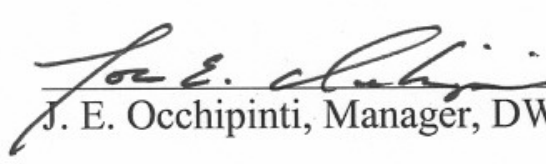

$6-01-05$

Date

$5 / 27 / 05$

Date

$6-10-05$

Date 


\section{EXECUTIVE SUMMARY}

Previous Savannah River National Laboratory (SRNL) melt rate tests in support of the Defense Waste Processing Facility (DWPF) have indicated that improvements in melt rate can be achieved through an increase in the total alkali of the melter feed. Higher alkali can be attained by the use of an "underwashed" sludge, a high alkali frit, or a combination of the two. Although the general trend between melt rate and total alkali (in particular $\mathrm{Na}_{2} \mathrm{O}$ content) has been demonstrated, the question of "does the source of alkali (SOA) matter?" still exists. Therefore the purpose of this set of tests was to determine if the source of alkali (frit versus sludge) can impact melt rate.

The general test concept was to transition from a $\mathrm{Na}_{2} \mathrm{O}$-rich frit to a $\mathrm{Na}_{2} \mathrm{O}$-deficient frit while compensating the $\mathrm{Na}_{2} \mathrm{O}$ content in the sludge to maintain the same overall $\mathrm{Na}_{2} \mathrm{O}$ content in the melter feed. Specifically, the strategy was to vary the amount of alkali in frits and in the sludge batch 3 (SB3) sludge simulant (midpoint or baseline feed was SB3/Frit 418 at $35 \%$ waste loading) so that the resultant feeds had the same final glass composition when vitrified.

A set of SOA feeds using frits ranging from 0 to 16 weight $\% \mathrm{Na}_{2} \mathrm{O}$ (in $4 \%$ increments) was first tested in the Melt Rate Furnace (MRF) to determine if indeed there was an impact. The dry-fed MRF tests indicated that if the alkali is too depleted from either the sludge $\left(16 \% \mathrm{Na}_{2} \mathrm{O}\right.$ feed) or the frit (the $0 \% \mathrm{Na}_{2} \mathrm{O}$ feed), then melt rate was negatively impacted when compared to the baseline SB3/Frit 418 feed currently being processed at DWPF. The MRF melt rates for the 4 and $12 \%$ SOA feeds were similar to the baseline SB3/Frit 418 (8\% SOA) feed.

Due to this finding, a smaller subset of SOA feeds that could be processed in the DWPF (4 and 12\% SOA feeds) was then tested in the Slurry-fed Melt Rate Furnace (SMRF). The results from a previous SMRF test with SB3/Frit 418 (Smith et al. 2004) were used as the SMRF melt rate of the baseline feed. The SOA SMRF test results agreed with those of the MRF tests for these two feeds as the melt rates were similar to the baseline SB3/Frit 418 feed. In other words, the source of alkali was close enough to the baseline feed as to not negatively impact melt rate. Based on these results, there appears to be an acceptable range of the source of alkali that results in the highest melt rate for a particular sludge batch. If, however, the alkali is too depleted from either the sludge or the frit, then melt rate will be lower. Although SB3 simulant sludge and Frit 418 were used for these tests, it was not the intent of these tests to determine an optimum source of alkali range for SB3. Rather, the findings of these tests should be used to help in the decision process for future sludge batch washing and/or blending strategies. The results, however, do confirm that the current processing of SB3 is being performed in the proper source of alkali range.

Because all of this testing was performed on small-scale equipment with slurried, non-radioactive simulant, the exact impact of the source of alkali with SB3 in the DWPF melter could not be fully evaluated. 


\section{TABLE OF CONTENTS}

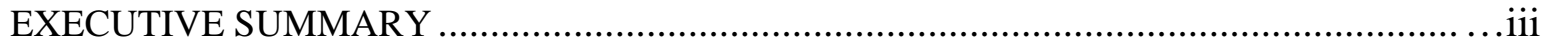

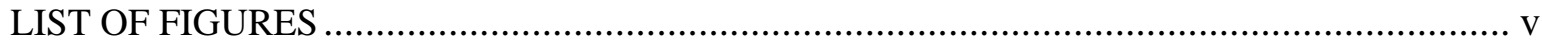

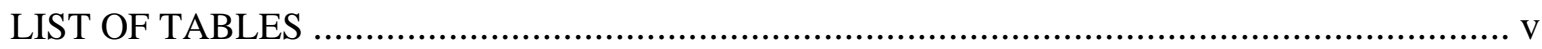

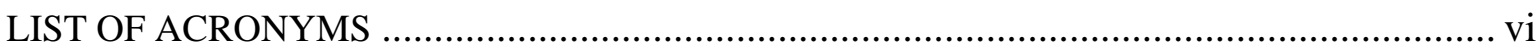

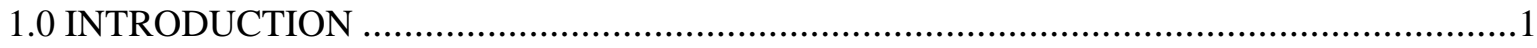

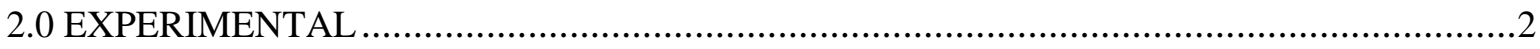

2.1 4-L SRAT and 22-L SRAT/SME Feed Preparation Details...............................................2

2.2 MRF SOA Testing Details..........................................................

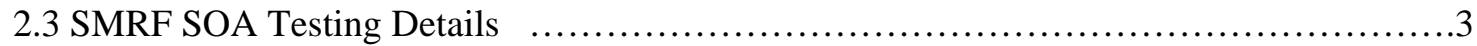

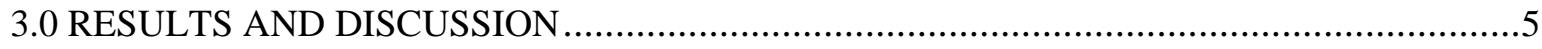

3.1 MRF SOA Results...................................................................

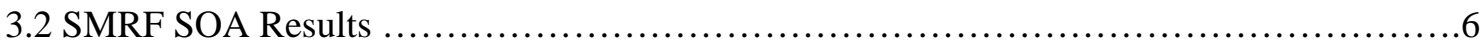

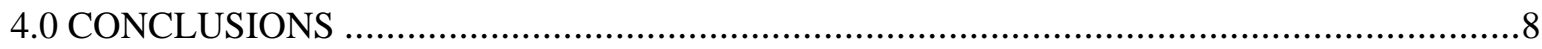

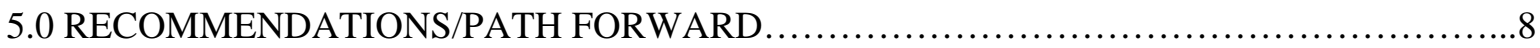

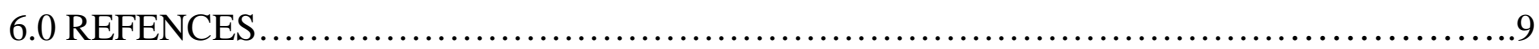

Appendix A - Analyses of the SOA Frits Made for the MRF and SMRF SOA Tests...............10

Appendix B - Target Compositions (Oxide Basis) for the SOA Sludges........................13

Appendix C - Analyses of the SOA MRF Glasses and SOA SMRF Feeds.......................15

Appendix D - Cross-Sections of MRF SOA Test Beakers.....................................17 


\section{LIST OF FIGURES}

Figure 3-1. Impact of SOA on Melt Rate (LMR- in/hr) and Waste Throughput Factor...............5

\section{LIST OF TABLES}

Table 2-1. Target SOA Frit Compositions (Weight \%)... .....................................

Table 2-2. Target Waste Loadings for the SOA Feed MRF and SMRF Tests........................2

Table 2-3. Rheological Properties of the SMRF SOA Feeds Before and After Dilution................4

Table 3-1. Melt Rates (LMR) and Waste Throughput Factors (WTF) for the MRF SOA Tests.........5

Table 3-2. Melt Rates (g/min) for the SMRF SOA Tests....................................

Table 3-3. SMRF Vapor Space and Melt Pool Heater Power (BTU/min) Usages for the SOA Tests...7 


\section{LIST OF ACRONYMS}

$\begin{array}{ll}\text { CPC } & \text { Chemical Process Cell } \\ \text { DSC } & \text { Differential Scanning Calorimetry } \\ \text { DWPF } & \text { Defense Waste Processing Facility } \\ \text { HTXRD } & \text { High Temperature X-Ray Diffraction } \\ \text { LMR } & \text { Linear Melt Rate } \\ \text { MRF } & \text { Melt Rate Furnace } \\ \text { REDOX } & \text { REDuction/OXidation } \\ \text { SB2 } & \text { Sludge Batch 2 } \\ \text { SB3 } & \text { Sludge Batch 3 } \\ \text { SEM/EDS } & \text { Scanning Electron Microscopy/Energy-Dispersive Spectroscopy } \\ \text { SME } & \text { Slurry Mix Evaporator } \\ \text { SMRF } & \text { Slurry-Fed Melt Rate Furnace } \\ \text { SOA } & \text { Source of Alkali } \\ \text { SRAT } & \text { Sludge Receipt and Adjustment Tank } \\ \text { SRNL } & \text { Savannah River National Laboratory } \\ \text { TGA } & \text { Thermogravimetric Analysis } \\ \text { WSRC } & \text { Westinghouse Savannah River Company } \\ \text { WTF } & \text { Waste Throughput Factor }\end{array}$




\subsection{INTRODUCTION}

Previous melt rate tests have indicated that improvements in melt rate can be achieved through an increase in the total alkali of the melter feed. Higher alkali can be attained by the use of an "underwashed" sludge, a high alkali frit, or a combination of the two. Although the general trend between melt rate and total alkali (in particular $\mathrm{Na}_{2} \mathrm{O}$ content) has been demonstrated, the question of "does the source of alkali (SOA) matter?" still exists. Therefore the purpose of this set of tests was to determine if the source of alkali (frit versus sludge) can impact melt rate. This was done with the understanding that the source of alkali may impact acid stoichiometry requirements and hence rheology of the feeds as well as the tendency of the feed to cause problematic off-gas surges in the melter.

The general test concept was to transition from a $\mathrm{Na}_{2} \mathrm{O}$-rich frit to a $\mathrm{Na}_{2} \mathrm{O}$-deficient frit while compensating the $\mathrm{Na}_{2} \mathrm{O}$ content in the sludge to maintain the exact overall $\mathrm{Na}_{2} \mathrm{O}$ content in the melter feed. If the source of alkali does impact melt rate and ultimately overall waste throughput, this series of tests may allow SRNL to provide guidance on the washing and/or blending strategies for future sludge batches. The approach for this series of tests was to vary the amount of alkali in frits and in the SB3 sludge simulant (midpoint or baseline feed was SB3/Frit 418 at 35\% waste loading) so that the resultant feeds had the same final glass composition when vitrified. The feeds for these SOA tests are described based on the percent $\mathrm{Na}_{2} \mathrm{O}$ that is in the frit for that feed. For example, SOA test feed that used a frit with 4 weight $\% \mathrm{Na}_{2} \mathrm{O}$ was called $4 \%$ SOA feed. Therefore the baseline SB3/Frit 418 feed is called $8 \%$ SOA feed as Frit 418 has $8 \% \mathrm{Na}_{2} \mathrm{O}$.

The waste loadings of these feeds were varied to keep the final glass composition constant. The goal was to also maintain the acid stoichiometry and the REDuction/OXidation (REDOX) constant at the current DWPF targets for each. Therefore an acid stoichiometry of $155 \%$ was selected for the range of sludge compositions to be tested. The target REDOX was 0.2 but as long as the final REDOX was within the range of 0.1 to 0.33 , no impact on melt rate was expected based on previous testing (Smith et al. 2004). A set of SOA feeds using frits ranging from 0 to $16 \% \mathrm{Na}_{2} \mathrm{O}$ (in $4 \%$ increments) was first tested in the MRF to determine if indeed there was an impact. Because an impact was observed in the MRF tests, a smaller subset of SOA feeds (4 and 12\% SOA feeds) was then tested in the SMRF. The results from a previous SMRF test with SB3/Frit 418 (Smith et al. 2004) were used as the SMRF melt rate of the baseline feed.

This task was initiated by DWPF Engineering via Task Technical Request (TTR) HLW-DWPF-20040030 to SRNL. The work was performed per Task Technical and Quality Assurance Plan WSRC-RP2004-00713.

Tests were performed with non-radioactive, simulated SB3 material. Due to the small-scale of the test equipment and the design of the equipment, as well as the use of dry or slurried, non-radioactive simulant feed, the behavior of the actual radioactive feed in the DWPF melter cannot be fully proven. 


\subsection{EXPERIMENTAL}

\subsection{4-L SRAT and 22-L SRAT/SME Feed Preparation Details}

The SOA tests were conducted using the current SB3 sludge simulant and process strategy (155\% acid stoichiometry, 0.2 REDOX, Frit 418, and 35\% waste loading) as the baseline (Smith et al. 2004). Frit 418 contains $8 \% \mathrm{Na}_{2} \mathrm{O}$ as well other oxides given in Table 2-1. Frit compositions were targeted at approximately $0,4,12$, and $16 \% \mathrm{Na}_{2} \mathrm{O}$ with all other test frit species then being renormalized from the baseline Frit 418. The amount of sodium in the sludge as well as the waste loading was adjusted to maintain a constant glass composition for each of the feeds tested.

A comparison of the target compositions of the SOA frits is given below in Table 2-1. The frits (except Frit 418) are named SOA frits with the amount of $\mathrm{Na}_{2} \mathrm{O}$ in the frit given in the description. For example, the SOA frit with a target of $4 \% \mathrm{Na}_{2} \mathrm{O}$ is called $4 \%$ SOA frit. In addition, the resultant feed made with each SOA frit is named based on the amount of $\mathrm{Na}_{2} \mathrm{O}$ in the frit used. For example, the SOA feed using the 4\% SOA frit is called 4\% SOA feed. Appendix A gives the actual compositions of all of the SOA frits made for the MRF and SMRF SOA tests.

Table 2-1. Target SOA Frit Compositions (Weight \%)

\begin{tabular}{||c|c|c|c|c|c||}
\hline \hline Oxide & $\begin{array}{c}\text { 0\% SOA } \\
\text { Frit }\end{array}$ & $\begin{array}{c}\text { 4\% SOA } \\
\text { Frit }\end{array}$ & $\begin{array}{c}\text { Frit 418 } \\
\text { (8\% SOA) }\end{array}$ & $\begin{array}{c}\text { 12\% SOA } \\
\text { Frit }\end{array}$ & $\begin{array}{c}\text { 16\% SOA } \\
\text { Frit }\end{array}$ \\
\hline $\mathrm{B}_{2} \mathrm{O}_{3}$ & 8.69 & 8.35 & 8 & 7.66 & 7.32 \\
\hline $\mathrm{Li}_{2} \mathrm{O}$ & 8.69 & 8.35 & 8 & 7.66 & 7.32 \\
\hline $\mathrm{Na}_{2} \mathrm{O}$ & 0.05 & 4.02 & 8 & 11.95 & 15.80 \\
\hline $\mathrm{SiO}_{2}$ & 82.57 & 79.29 & 76 & 72.73 & 69.55 \\
\hline Total & 100 & 100 & 100 & 100 & 100 \\
\hline
\end{tabular}

Sludge was produced for each test by blending the existing SB2 and SB3 simulants and then adding trim species as required to meet composition requirements. Sodium is present in the sludge as a number of species, including carbonate, fluoride, hydroxide, nitrate, nitrite, phosphate, and sulfate. In order to maintain a constant glass composition, the fluoride, phosphate, and sulfate were held constant during the tests. The amount of carbonate, hydroxide, nitrate, and nitrite was adjusted in proportion to meet the required sodium concentrations in the sludge. Appendix B gives the targeted sludge compositions for the SOA tests.

Waste loading adjustment was required since removal of sodium from the frit requires less frit in the glass to maintain constant boron oxide, lithia, and silica concentrations because the concentration of these species in the frit increases as sodium is removed. Therefore, waste loading was decreased as the sodium concentration of the sludge was decreased. The reduction in $\mathrm{Na}_{2} \mathrm{O}$ content in the sludge corresponds to additional washing. Likewise, waste loading was increased as the sludge washing was decreased and less sodium was added to the frit. Table 2-2 gives the target waste loadings for the various SOA feeds.

Table 2-2. Target Waste Loadings for the SOA Feed MRF and SMRF Tests

\begin{tabular}{||c|c||}
\hline SOA Feed & Target WL \\
\hline $0 \%$ SOA & 40.2 \\
\hline $4 \%$ SOA & 37.7 \\
\hline SB3/Frit 418 (8\%SOA) & 35.0 \\
\hline $12 \%$ SOA & 32.1 \\
\hline $16 \%$ SOA & 29.0 \\
\hline
\end{tabular}


The sludge was processed through lab-scale simulations of the Chemical Process Cell (CPC) process to provide feed for the melt rate program. Five Sludge Receipt and Adjustment Tank (SRAT) cycles were performed to make the $0 \%, 4 \%, 8 \%, 12 \%$ and $16 \%$ SOA sludges in $4-\mathrm{L}$ vessels. This provided five $2.5-\mathrm{L}$ batches of slurry to be dried as feed for the MRF SOA tests. Four SRAT/Slurry Mix Evaporator (SME) cycles were performed in 22-L vessels to provide four 14-L batches of slurry feed for the SMRF tests. These feeds consisted of two 14-L batches each of 4 and 12\% SOA feeds. After review of all of the feed analyses, all SOA SRAT (for the MRF tests) and SRAT/SME (for the SMRF tests) products were deemed acceptable for use in the tests.

One of the main SOA test premises is that all of the feeds and hence final glass compositions for the various SOA feeds were basically the same. For MRF tests, the SRAT product is analyzed and the proper amount of frit is added but this feed is usually not analyzed. To ensure that indeed the final glasses compositions were the same for all of the MRF SOA tests, samples of each of the MRF glasses produced were taken and analyzed to confirm this premise. For the SMRF tests, feed samples for the two SOA feeds were compared with the previous tested SB3/Frit 418 SMRF feed that was used to determine the 8\% SOA feed melt rate (Smith et al. 2004). Appendix C gives the analyses of all of these samples. Indeed, all of the MRF SOA glasses and the SMRF SOA feeds were very similar in composition.

The run plans for the five 4-L SRAT runs for MRF tests are given in SRNL inter-office memorandums SRT-GPD-2004-00084, SRT-GPD-2004-00085, SRT-GPD-2004-00086, SRT-GPD-2004-00087, and SRT-GPD-2004-00088. The run plan for the 22-L SRAT/SME runs for the SMRF tests are given in SRNL inter-office memorandums SRT-GPD-2005-00012 and SRT-GPD-2005-00013. Details of the 4-L SRAT runs for the MRF SOA tests and the 22-L SRAT/SME runs for the SMRF SOA tests are documented by Lambert and Stone (2005).

\subsection{MRF SOA Testing Details}

The dry-fed MRF has a cylindrical inner chamber that is approximately 0.5 cubic feet in size, with heating coils winding around the chamber walls. The diameter of the chamber is $\sim 7$ ”, and an insulating sleeve and a $1200 \mathrm{~mL}$ stainless steel beaker (6” deep) were inserted from the top. The tests were conducted with the stainless steel beakers inserted with the sleeve so that the beaker bottom was approximately flush with the top of the uppermost chamber coil. An insulating block was used to cover the beaker. The furnace was heated to $1150^{\circ} \mathrm{C}$ with the top opening covered. Once the furnace reached the setpoint, the cover was removed and the beaker containing sufficient dried, sieved material to produce 500 grams of glass was inserted. After 50 minutes, the beaker was removed from the furnace and allowed to cool to room temperature. This residence time in the furnace was determined during testing in 2002 to establish a standard test time for melt rate comparison for this dry-fed furnace (Lorier et al. 2002). After cooling down, the beakers are then sectioned.

The relative melt rate is determined by measuring the height of the glass layer in the bottom of each sectioned beaker at 0.25 ” intervals. The average height and duration in the furnace is used to yield a relative linear melt rate number (inches/hour). General observations of the sectioned beaker are also used to describe differences between runs. A volumetric estimate of melt rate is also calculated, but the linear method is the basis for comparison in this and other reports. In general, the volumetric and linear values show similar results.

\subsection{SMRF SOA Testing Details}

The SMRF was heated up on February 14, 2005 with 6.4 kg of a prefabricated SB3 Frit 418 glass targeting 35\% waste loading. The run plan used for the SMRF tests was SRT-GPD-2005-00005 ("Run 
Plan for the Source of Alkali Runs in the Slurry Fed Melter Rate Furnace”). The SRNL notebook used was WSRC-NB-2004-00123. SMRF SOA testing of SOA $4 \%$ and SOA $12 \%$ feeds were conducted the following two days.

Details about the SMRF are documented elsewhere by Smith et al. (2003). The melt pool and vapor space setpoints were $1125^{\circ} \mathrm{C}$ and $750^{\circ} \mathrm{C}$ respectively. The time for each feed cycle after the vapor space had reached the feed initiation setpoint of $750^{\circ} \mathrm{C}$ was 20 seconds. As in past SMRF runs, the measured current for the melt pool and vapor space heaters were both about 20 amps for the two tests.

Before the testing was started, it was noted that the $12 \%$ SOA feed was very thick. The thickness of the feed was probably because the total acid requirement was low for this overwashed sludge. Therefore the feeding of this $12 \%$ SOA feed with the SMRF feed system was tested before the SMRF was heated up. It was determined that this feed at 50 weight \% solids could not be pumped in the targeted amount (90-100 grams) per 20 second feed cycle. Some of this feed was diluted to 45 weight \% solids and feeding at the proper rate was accomplished. Therefore a decision was made to test the $12 \%$ SOA feed at 45 weight $\%$ solids only and to then test the $4 \%$ SOA feed at 50 weight \% solids and then at 45 weight $\%$ solids. This was so that direct melt rate comparisons could be made for the same feeds at the same weight percent solids. Measured rheological properties of the 4 and 12\% SOA SMRF feeds before and after dilution are given below in Table 2-3. Dilution of the $12 \%$ SOA feed to 45 weight \% solids lowered the yield stress to about the same value as the $4 \%$ SOA feed at 50 weight \% solids. A more detailed discussion about the rheological properties of the SOA SMRF feeds is given elsewhere (Lambert and Stone 2005).

Table 2-3. Rheological Properties of the SMRF SOA Feeds Before and After Dilution

\begin{tabular}{||c|c|c||}
\hline SOA Feed (Targeted Wt\% Solids) & $\begin{array}{c}\text { Consistency } \\
\text { (cP) }\end{array}$ & $\begin{array}{c}\text { Yield Stress } \\
\text { (Pa) }\end{array}$ \\
\hline 4\% SOA 22-L SME Run 1 (50) & 56.0 & 27.5 \\
\hline 4\% SOA 22-L SME Run 2 (50) & 94.0 & 32.7 \\
\hline *4\% SOA Feed (45) & 39.1 & 8.4 \\
\hline 12\% SOA 22-L SME Run 1 (50) & 193.0 & 71.4 \\
\hline 12\% SOA 22-L SME Run 2 (50) & 93.9 & 64.1 \\
\hline *12\% SOA Feed (45) & 53.9 & 34.0 \\
\hline
\end{tabular}

*Note: These feeds are the mixture of SME Runs 1 and 2 (SMRF SOA feed)

The feed dilution decision was also based on the fact that the reference (or baseline) SB3/Frit 418 feed had been tested at both 50 and 45 weight \% solids as documented by Smith, et al. (2004). The SMRF SOA targeted test conditions were the same as this previously run baseline SB3/Frit 418 test. This allowed the best possible comparison of the three feeds. The melt rate results of this SB3/Frit 418 SMRF test (155\% acid stoichiometry, 0.2 REDOX, 35\% waste loading) were used as the baseline melt rates (8\% SOA feed at 45 and 50 weight \% solids) for the SOA tests. 


\subsection{RESULTS AND DISCUSSION}

\subsection{MRF SOA Results}

The results of the MRF SOA tests (melt rate and waste throughput factor or WTF) are shown in Table 3-1. The melt rates cited are linear melt rates (LMR) with the units being inches/hour of melt time. Waste throughput factor (WTF) is calculated as follows:

$$
\text { WTF }=\text { LMR x WL (waste loading) }
$$

Figure 3-1 is a plot of the impact of SOA on melt rate and waste throughput factor.

Table 3-1. Melt Rates (LMR) and Waste Throughput Factors (WTF) for the MRF SOA Tests

\begin{tabular}{||c|c|c||}
\hline \hline SOA MRF Feed & LMR (in/hr) & WTF (Target WL) \\
\hline 0\% SOA & 0.39 & $15.7(40.2)$ \\
\hline 4\% SOA & 0.55 & $20.7(37.7)$ \\
\hline SB3/Frit 418 (8\%SOA) & 0.59 & $20.7(35.0)$ \\
\hline 12\% SOA & 0.55 & $17.7(32.1)$ \\
\hline 16\% SOA & 0.38 & $11.0(29.0)$ \\
\hline
\end{tabular}

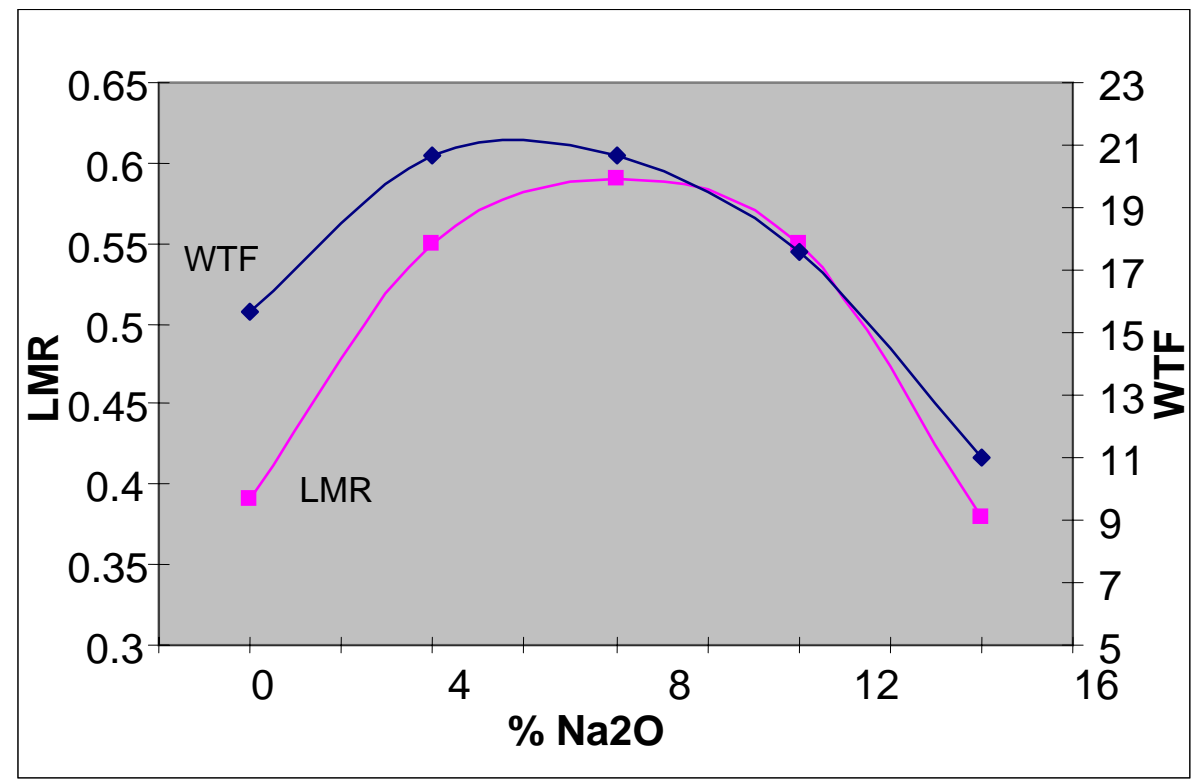

Figure 3-1. Impact of SOA on Melt Rate (LMR - in/hr) and Waste Throughput Factor

The highest linear melt rate was achieved with the 8\% SOA feed (SB3/Frit 418 baseline feed). The 4\% and $12 \%$ SOA feeds, however, had linear melt rates that were almost as high (both at $0.55 \mathrm{in} / \mathrm{hr}$ vs. 0.59 $\mathrm{in} / \mathrm{hr}$ for the $8 \%$ SOA feed). Indeed, these three melt rates could be considered as basically equivalent. A significant drop off in melt rate (approximately 30\%) was observed for the $0 \%$ and $16 \%$ SOA feeds. The data indicates that there is an optimum range in the source of alkali that gives the highest melt rate. If the alkali is too depleted from either the frit (underwashed sludge) or from the sludge (overwashed sludge), then melt rate and waste throughput will be negatively impacted. The one difference in the 
LMR and WTF curves is that the WTF peak is shifted slightly to lower SOA feeds (closer to 4\% SOA feed). Part of this shift may be because there is more sodium in the waste. Appendix D has pictures of the some of the SOA MRF test beakers after they were cross-sectioned. It was observed that the $0 \%$ SOA MRF test resulted in expansion of the unmolten feed to the point that it lifted the M-board cover that is placed on top of each MRF beaker about one inch. The beakers shown in Appendix D were cut in such a way that this feed expansion was removed before the post $0 \%$ SOA MRF test picture was taken.

The reasons for the decrease in melt rate with the 0 and 16\% SOA feeds could not be determined with these tests. However, theories can be made as to the causes in the drop in melt rate for these two feeds. For the $0 \%$ SOA feed, there are several possible drivers. First, the frit is the most refractory of all the frits used. Therefore melting (or liquid phase formation) may be only occurring near the hot glass section of the cold cap. In addition, the sludge was the least washed (requiring higher amounts of acid addition and also more anions being released as off-gas during the melting process) of those tested and targeted the highest waste loading (40.2\%) to maintain the same final glass composition. Both of these factors would cause the amount of off-gas to be higher, thereby potentially reducing heat transfer efficiencies which would negatively impact melt rate. With the $16 \%$ SOA feed (i.e. the most washed), the refractoriness (lowest amount of sodium) of the sludge may have resulted in minimal liquid state formation. In addition, the $16 \%$ SOA frit would have been the most fluid (for a given temperature), but it could be melting or softening in a temperature range that would trap off-gas from reactions occurring in the cold cap. This could result in foam formation which would inhibit heat transfer in the cold cap.

Finally, there has been some question about the overall repeatability of the MRF melt rate results. Including the 8\% MRF SOA test results documented in this report, there have been four different MRF runs that used SB3 SRAT product with Frit 418 at 35\% WL and similarly targeted acid stoichiometry and REDOX. All four of these tests had linear melt rates in the range of 0.58 to 0.60 inches/hour. This data indicates that indeed the MRF can give fairly repeatable melt rate results.

\subsection{SMRF SOA Results}

Details of the SMRF SOA runs are given in Section 2.3. The $4 \%$ SOA (at 50 and 45 weight \% solids) and $12 \%$ SOA (at 45 weight $\%$ solids) feeds were tested. As discussed previously, the $12 \%$ SOA feed at 50 weight \% solids was not tested as it could not be pumped at the target rate of 90-100 grams per 20 second feed cycle. The results of these tests were compared to the SMRF melt rates of a previously run 8\% SOA feed (SB3/Frit 418 feed at $35 \%$ waste loading) as documented by Smith et al. (2004). It should be noted that the feeds cited in Table 3-3 of this reference report were not named correctly. The names for the 185/50 feed (185 \% acid stoichiometry/50 weight \% solids) and the $155 / 45$ feed (155 \% acid stoichiometry/45 weight \% solids) were erroneously switched. This error does not change the overall findings of that report, but is discussed here to ensure that there is no confusion with the SMRF melt rates of those tests as cited in this document. Table 3-2 summarizes the results of the SMRF SOA tests. Melt rate values are given in grams/minute. Tables 3-3 summarizes the vapor space and melt pool heater power usages for the tests. The data shows that the power usages were similar for these tests.

Table 3-2. Melt Rates (g/min) for the SMRF SOA Tests

\begin{tabular}{||c|c|c|c||}
\hline & $\mathbf{4 \%}$ SOA Feed & $\boldsymbol{* 8 \%}$ SOA Feed & $\mathbf{1 2 \%}$ SOA Feed \\
\hline 50 weight \% solids & 13.8 & 14.1 & --- \\
\hline 45 weight \% solids & 14.4 & $* * 11.5 / 13.1$ & 13.6 \\
\hline
\end{tabular}

*baseline feed - SB3/Frit 418 at 35\% waste loading, 155\% acid stoichiometry, 0.2 REDOX (Smith, et al. 2004)

**test only lasted 2 hours and there were several feed stoppages. The pour rate for the last 17 minutes of the test was up to $13.1 \mathrm{~g} / \mathrm{min}$ and therefore is cited as a possible higher melt rate for this test. 
WSRC-TR-2005-00177

Table 3-3. SMRF Vapor Space and Melt Pool Heater Power (BTU/min) Usages for the SOA Tests

\begin{tabular}{||c|c|c|c||}
\hline & 4\% SOA (Vapor/Melt) & 8\% SOA (Vapor/Melt) & 12\% SOA (Vapor/Melt) \\
\hline 50 weight \% solids & $93.3 / 47.6$ & $95.6 / 48.4$ & --- \\
\hline 45 weight \% solids & $96.8 / 44.3$ & $97.3 / 45.5$ & $95.6 / 49.5$ \\
\hline
\end{tabular}

The results of the tests are somewhat difficult to compare. One thing to note is that the SMRF top was taken off and then replaced after a series of sight glass tests were performed for a proposed larger melter tool. The first SMRF tests run after this top head replacement was this series of SOA tests. The impact of this top head removal and replacement (same top head) is unknown, although it should be minimal.

The melt rates for the 4\% SOA and $8 \%$ SOA feeds (at 50 weight $\%$ solids) were similar. This agrees with MRF SOA tests. If the $12 \%$ SOA feed could have been tested at 50 weight $\%$ solids as well, a more definitive conclusion may have been possible.

The results for the feeds at 45 weight \% solids are somewhat more difficult to use for making any conclusions on the source of alkali. The slight increase in melt rate for the $4 \%$ SOA feed when it was diluted from 50 to 45 weight \% solids could be explained in that melt rates were so close that they could be considered as equal. As given in the notes below Table 3-2, the results of the $8 \%$ SOA test may not be correct due to the shortness of the test and the problems that occurred during the test. If the melt rate for the last 17 minutes of the test is used $(13.1 \mathrm{~g} / \mathrm{min})$, then the results indicate that the melt rates for all three feeds are similar. This would again agree with the MRF SOA test results.

After considering all of the SMRF data as well as the various caveats discussed above, an overall conclusion from the SMRF SOA tests is that for the range of SOA feeds tested (4-12\%), the source of alkali had little impact on melt rate. The 0 and 16\% SOA feeds tested by the dry fed MRF were not run in the SMRF due to their low MRF melt rates, the processing problems observed during $0 \%$ SOA feed MRF testing, and the impractical amount of washing that would be required for the $16 \%$ SOA feed sludge. 


\subsection{CONCLUSIONS}

A series of dry-fed (using the MRF) and slurry-fed tests (using the SMRF) have been performed to investigate the impact of the source of alkali (frit versus sludge) on melt rate on the DWPF SB3/Frit 418 feed system. Due to some problems in testing such as the inability to feed the $12 \%$ SOA feed (at 50 weight \% solids) in the SMRF at the required rate per feed cycle, some direct comparisons of melt rates in the SMRF tests could not be made. The overall objective of the test was met, however, and the following conclusions can be made based on this work:

- The source of alkali (frit versus sludge) can impact melt rate as shown by the MRF SOA tests. From the MRF SOA tests findings, there appears to be a region for the source of alkali that results in the highest melt rates. If the alkali is too depleted from either the frit or the sludge, then melt rate is negatively impacted.

- The SMRF SOA tests agreed with the MRF tests in that the 4, 8, and $12 \%$ SOA feeds gave similar melt rates. The 0 and 16\% SOA feeds were not tested due to the much lower melt rates observed for both of these feeds in the MRF SOA tests, the processing problems observed during $0 \%$ SOA feed MRF testing, and the impractical amount of washing that would be required for the $16 \%$ SOA feed sludge.

- For the SB3/Frit 418 feed system, the current washing strategy is in the region of highest melt rate and waste throughput.

- Melt rates for DWPF sludge batches can be negatively impacted if the sludge is overwashed or underwashed.

\subsection{RECOMMENDATIONS/PATH FORWARD}

Based on the results of the SB3 SOA tests, the following recommendations are given:

- Thermal analysis techniques such as high temperature X-ray diffraction (HTXRD), quantitative X-ray diffraction, thermogravimetric analysis (TGA), differential scanning calorimetry (DSC), and scanning electron microscopy with energy-dispersive spectroscopy (SEM/EDS) should be performed on SB3 SOA feeds to access the impact of the source of alkali on the reaction pathways and kinetics during the batch to glass conversion process. The HTXRD work has already been started.

- The source of alkali should be considered when determining the sludge washing strategies and frits for future DWPF sludge batches to ensure the highest possible equivalent canister production rates. 


\subsection{REFERENCES}

Lambert, DP, and ME Stone. 2005. Feed Preparation for Source of Alkali Melt Rate Tests (U), WSRCTR-2005-00080, Westinghouse Savannah River Company, Aiken, South Carolina.

Lorier, TH, TM Jones, and DC Witt. 2002. Melt Rate Testing for the DWPF: Summary of FY02 Testing (U), WSRC-TR-2002-00545, Westinghouse Savannah River Company, Aiken, South Carolina.

Smith, ME, TH Lorier, and TM Jones. 2003. SMRF and MRF DWPF Melt Rate Testing for SB2/SB3 (Case 6b - 250 Canisters) (U), WSRC-TR-2003-00466, Westinghouse Savannah River Company, Aiken, South Carolina.

Smith, ME, DH Miller, and TL Lorier. 2004. The Impact of Feed Preparation Acid Stoichiometry and REDOX on Melt Rate for the SB3-Frit 418 System (U), WSRC-TR-2004-00350, Westinghouse Savannah River Company, Aiken, South Carolina. 


\section{APPENDIX A - ANALYSES OF THE SOA FRITS MADE FOR THE MRF AND SMRF TESTS}




\begin{tabular}{|c|c|c|c|c|c|c|c|c|c|}
\hline Sample ID & Lab ID & B & $\mathrm{Cr}$ & $\mathrm{Fe}$ & Li & $\mathrm{Na}$ & $\mathrm{Ni}$ & Si & \\
\hline $0 \%$ Na Frit (A) & 04-2151* & 2.83 & 0.016 & 0.049 & 4.16 & 0.090 & $<0.010$ & 38.6 & \\
\hline $0 \%$ Na Frit (B) & 04-2151* & 2.72 & 0.017 & 0.044 & 4.20 & 0.050 & $<0.010$ & 38.6 & \\
\hline $4 \%$ Na Frit (A) & 04-2176* & 2.66 & 0.003 & 0.048 & 3.79 & 3.17 & $<0.010$ & 37.6 & \\
\hline 4\% Na Frit (B) & 04-2176* & 2.68 & 0.003 & 0.043 & 3.80 & 3.12 & $<0.010$ & 38.1 & \\
\hline $12 \% \mathrm{Na}$ Frit (A) & 04-2151* & 2.45 & 0.018 & 0.055 & 3.66 & 8.98 & $<0.010$ & 33.9 & \\
\hline $12 \%$ Na Frit (B) & 04-2151* & 2.45 & 0.017 & 0.046 & 3.67 & 8.74 & $<0.010$ & 33.7 & \\
\hline $16 \%$ Na Frit (A) & 04-2151* & 2.39 & 0.017 & 0.040 & 3.54 & 11.6 & $<0.010$ & 32.7 & \\
\hline \multirow[t]{2}{*}{$16 \%$ Na Frit (B) } & 04-2151* & 2.32 & 0.017 & 0.043 & 3.52 & 11.5 & $<0.010$ & 31.8 & \\
\hline & & B2O3 & Cr2O3 & $\mathrm{Fe} 2 \mathrm{O3}$ & Li2O & $\mathrm{Na2O}$ & $\mathrm{NiO}$ & SiO2 & Total \\
\hline $0 \%$ Na Frit $(\mathrm{A})$ & 04-2151* & 9.11 & 0.023 & 0.070 & 8.94 & 0.122 & 0.000 & 82.6 & 101 \\
\hline $0 \%$ Na Frit (B) & 04-2151* & 8.76 & 0.025 & 0.063 & 9.03 & 0.068 & 0.000 & 82.6 & 101 \\
\hline \multirow[t]{2}{*}{ 0\% Na2O Frit } & Average & 8.94 & 0.02 & 0.07 & 8.99 & 0.09 & 0.00 & 82.60 & \\
\hline & Target & 8.69 & 0.00 & 0.00 & 8.69 & 0.05 & 0.00 & 82.60 & \\
\hline $4 \%$ Na Frit (A) & 04-2176* & 8.57 & 0.004 & 0.069 & 8.15 & 4.28 & 0.000 & 80.5 & 102 \\
\hline 4\% Na Frit (B) & 04-2176* & 8.63 & 0.004 & 0.061 & 8.17 & 4.21 & 0.000 & 81.5 & 103 \\
\hline \multirow[t]{2}{*}{ 4\% Na2O Frit } & Average & 8.60 & 0.00 & 0.07 & 8.16 & 4.25 & 0.00 & 81.00 & \\
\hline & Target & 8.35 & 0.00 & 0.00 & 8.35 & 4.02 & 0.00 & 79.29 & \\
\hline $12 \%$ Na Frit (A) & 04-2151* & 7.89 & 0.026 & 0.079 & 7.87 & 12.1 & 0.000 & 72.5 & 101 \\
\hline $12 \%$ Na Frit (B) & 04-2151* & 7.89 & 0.025 & 0.066 & 7.89 & 11.8 & 0.000 & 72.1 & 100 \\
\hline \multirow[t]{2}{*}{ 12\% Na2O Frit } & Average & 7.89 & 0.03 & 0.07 & 7.88 & 11.96 & 0.00 & 72.33 & \\
\hline & Target & 7.66 & 0.00 & 0.00 & 7.66 & 11.95 & 0.00 & 72.73 & \\
\hline $16 \% \mathrm{Na}$ Frit (A) & 04-2151* & 7.70 & 0.025 & 0.057 & 7.61 & 15.7 & 0.000 & 70.0 & 101 \\
\hline $16 \%$ Na Frit (B) & 04-2151* & 7.47 & 0.025 & 0.061 & 7.57 & 15.5 & 0.000 & 68.1 & 98.7 \\
\hline \multirow[t]{2}{*}{ 16\% Na2O Frit } & Average & 7.58 & 0.02 & 0.06 & 7.59 & 15.59 & 0.00 & 69.02 & \\
\hline & Target & 7.32 & 0.00 & 0.00 & 7.32 & 15.80 & 0.00 & 69.55 & \\
\hline
\end{tabular}

TABLE A-1. Analyses of the SOA Frits Used for the MRF SOA Tests 
SRTC Mobile Laboratory

Customer: David Peeler

Date: $1 / 28 / 05$

Samples: 12\% Na Frit 1, 2, 3 - 4\% Na Frit 1, 2, 3

Lab ID: 05-0079 through 05-0084

Units: elemental and oxide wt\%

Sample Preparation: LiBO2 and Na2O2 Preps

Comments: Samples run in duplicate

\begin{tabular}{|c|c|c|c|c|c|c|c|c|c|}
\hline Sample ID & Lab ID & B & $\mathrm{Cr}$ & $\mathrm{Fe}$ & $\mathrm{Li}$ & $\mathrm{Na}$ & $\mathrm{Ni}$ & Si & \\
\hline $12 \%$ Na Frit $1(\mathrm{~A})$ & $05-0079$ & 2.42 & 0.012 & 0.058 & 3.34 & 9.02 & $<0.010$ & 34.2 & \\
\hline 12\% Na Frit 1 (B) & $05-0079$ & 2.43 & 0.013 & 0.055 & 3.41 & 8.76 & $<0.010$ & 34.2 & \\
\hline 12\% Na Frit $2(\mathrm{~A})$ & $05-0080$ & 2.39 & 0.014 & 0.068 & 3.29 & 8.61 & $<0.010$ & 33.2 & \\
\hline 12\% Na Frit 2 (B) & $05-0080$ & 2.40 & 0.014 & 0.064 & 3.30 & 8.70 & $<0.010$ & 33.9 & \\
\hline $12 \%$ Na Frit $3(\mathrm{~A})$ & $05-0081$ & 2.40 & 0.014 & 0.048 & 3.39 & 8.84 & $<0.010$ & 33.8 & \\
\hline $12 \%$ Na Frit $3(B)$ & $05-0081$ & 2.34 & 0.013 & 0.059 & 3.31 & 8.80 & $<0.010$ & 33.1 & \\
\hline 4\% Na Frit 1 (A) & $05-0082$ & 2.62 & 0.015 & 0.055 & 3.67 & 3.08 & $<0.010$ & 37.3 & \\
\hline 4\% Na Frit 1 (B) & $05-0082$ & 2.62 & 0.015 & 0.052 & 3.66 & 2.93 & $<0.010$ & 37.2 & \\
\hline 4\% Na Frit 1 (A) & $05-0083$ & 2.85 & 0.015 & 0.083 & 3.66 & 2.96 & $<0.010$ & 37.7 & \\
\hline 4\% Na Frit 1 (B) & $05-0083$ & 2.77 & 0.014 & 0.090 & 3.59 & 2.94 & $<0.010$ & 37.4 & \\
\hline 4\% Na Frit $1(\mathrm{~A})$ & $05-0084$ & 2.76 & 0.015 & 0.052 & 3.51 & 3.02 & $<0.010$ & 36.6 & \\
\hline 4\% Na Frit 1 (B) & $05-0084$ & 2.78 & 0.014 & 0.051 & 3.52 & 2.93 & $<0.010$ & 37.4 & \\
\hline & & & & & & & & & \\
\hline & & B2O3 & $\mathrm{Cr} 2 \mathrm{O3}$ & $\mathrm{Fe} 2 \mathrm{O3}$ & Li2O & $\mathrm{Na2O}$ & $\mathrm{NiO}$ & SiO2 & Total \\
\hline $12 \%$ Na Frit $1(\mathrm{~A})$ & 05-0079 & 7.79 & 0.018 & 0.083 & 7.18 & 12.2 & 0.000 & 73.2 & 100 \\
\hline 12\% Na Frit 1 (B) & $05-0079$ & 7.82 & 0.019 & 0.079 & 7.33 & 11.8 & 0.000 & 73.2 & 100 \\
\hline $12 \%$ Na Frit $2(\mathrm{~A})$ & $05-0080$ & 7.70 & 0.020 & 0.097 & 7.07 & 11.6 & 0.000 & 71.0 & 97.6 \\
\hline 12\% Na Frit 2 (B) & $05-0080$ & 7.73 & 0.020 & 0.092 & 7.10 & 11.7 & 0.000 & 72.5 & 99.2 \\
\hline $12 \%$ Na Frit $3(\mathrm{~A})$ & $05-0081$ & 7.73 & 0.020 & 0.069 & 7.29 & 11.9 & 0.000 & 72.3 & 99.4 \\
\hline $12 \%$ Na Frit $3(B)$ & $05-0081$ & 7.53 & 0.019 & 0.084 & 7.12 & 11.9 & 0.000 & 70.8 & 97.5 \\
\hline Average & & 7.72 & 0.02 & 0.08 & 7.18 & 11.86 & 0.00 & 72.19 & 99.06 \\
\hline Target & & 7.66 & 0.00 & 0.00 & 7.66 & 11.95 & 0.00 & 72.73 & \\
\hline 4\% Na Frit $1(\mathrm{~A})$ & $05-0082$ & 8.44 & 0.022 & 0.079 & 7.89 & 4.16 & 0.000 & 79.8 & 100 \\
\hline 4\% Na Frit 1 (B) & $05-0082$ & 8.44 & 0.022 & 0.074 & 7.87 & 3.96 & 0.000 & 79.6 & 100 \\
\hline $4 \%$ Na Frit $1(\mathrm{~A})$ & $05-0083$ & 9.18 & 0.022 & 0.119 & 7.87 & 4.00 & 0.000 & 80.7 & 102 \\
\hline 4\% Na Frit 1 (B) & $05-0083$ & 8.92 & 0.020 & 0.129 & 7.72 & 3.97 & 0.000 & 80.0 & 101 \\
\hline 4\% Na Frit 1 (A) & $05-0084$ & 8.89 & 0.022 & 0.074 & 7.55 & 4.08 & 0.000 & 78.3 & 98.9 \\
\hline 4\% Na Frit 1 (B) & $05-0084$ & 8.95 & 0.020 & 0.073 & 7.57 & 3.96 & 0.000 & 80.0 & 101 \\
\hline Average & & 8.80 & 0.02 & 0.09 & 7.74 & 4.02 & 0.00 & 79.75 & 100.43 \\
\hline Target & & 8.35 & 0.00 & 0.00 & 8.35 & 4.02 & 0.00 & 79.29 & \\
\hline
\end{tabular}

TABLE A-2. Analyses of the $4 \%$ and $12 \%$ SOA Frits Used for the SMRF SOA Tests

\section{$12 \% \mathrm{Na}$ Li2O Norm $\quad 4 \% \mathrm{Na}$ Li2O Norm}

$$
\begin{array}{ll}
7.25 & 7.71
\end{array}
$$




\section{APPENDIX B - TARGET COMPOSITIONS (OXIDE BASIS) FOR THE SOA SLUDGES}




\begin{tabular}{||c|c|c|c|c|c||}
\hline \hline OXIDE & $\begin{array}{c}\text { 0\% SOA } \\
\text { SLUDGE }\end{array}$ & $\begin{array}{c}\text { 4\% SOA } \\
\text { SLUDGE }\end{array}$ & $\begin{array}{c}\text { 8 \% SOA } \\
\text { SLUDGE }\end{array}$ & $\begin{array}{c}\text { 12\% SOA } \\
\text { SLUDGE }\end{array}$ & $\begin{array}{c}\text { 16\% SOA } \\
\text { SLUDGE }\end{array}$ \\
\hline $\mathrm{Al} 2 \mathrm{O} 3$ & 14.82 & 15.79 & 17.01 & 18.56 & 20.55 \\
\hline $\mathrm{Ag} 2 \mathrm{O}$ & 0.02 & 0.02 & 0.02 & 0.02 & 0.02 \\
\hline $\mathrm{BaO}$ & 0.12 & 0.13 & 0.14 & 0.16 & 0.17 \\
\hline $\mathrm{CaO}$ & 3.19 & 3.40 & 3.67 & 4.00 & 4.43 \\
\hline $\mathrm{Cr} 2 \mathrm{O} 3$ & 0.20 & 0.22 & 0.23 & 0.25 & 0.28 \\
\hline $\mathrm{CuO}$ & 0.17 & 0.18 & 0.19 & 0.21 & 0.23 \\
\hline $\mathrm{Fe} 2 \mathrm{O} 3$ & 36.07 & 38.44 & 41.40 & 45.17 & 50.01 \\
\hline $\mathrm{Gd} 2 \mathrm{O} 3$ & 0.07 & 0.07 & 0.08 & 0.08 & 0.09 \\
\hline $\mathrm{K} 2 \mathrm{O}$ & 0.04 & 0.04 & 0.04 & 0.05 & 0.05 \\
\hline $\mathrm{MgO}$ & 3.71 & 3.95 & 4.26 & 4.64 & 5.14 \\
\hline $\mathrm{MnO}$ & 5.65 & 6.02 & 6.48 & 7.07 & 7.83 \\
\hline $\mathrm{Na2O}$ & 30.84 & 26.30 & 20.63 & 13.41 & 4.13 \\
\hline $\mathrm{NiO}$ & 1.11 & 1.18 & 1.27 & 1.39 & 1.54 \\
\hline $\mathrm{P} 2 \mathrm{O} 5$ & 0.19 & 0.21 & 0.22 & 0.24 & 0.27 \\
\hline $\mathrm{PbO}$ & 0.06 & 0.06 & 0.07 & 0.07 & 0.08 \\
\hline $\mathrm{RhO} 2$ & 0.01 & 0.01 & 0.01 & 0.02 & 0.02 \\
\hline $\mathrm{RuO} 2$ & 0.06 & 0.06 & 0.07 & 0.07 & 0.08 \\
\hline $\mathrm{SiO} 2$ & 2.03 & 2.17 & 2.33 & 2.55 & 2.82 \\
\hline $\mathrm{ZnO}$ & 0.33 & 0.35 & 0.37 & 0.41 & 0.45 \\
\hline $\mathrm{ZrO} 2$ & 0.35 & 0.37 & 0.40 & 0.43 & 0.48 \\
\hline $\mathrm{SO} 4$ & 0.96 & 1.03 & 1.10 & 1.20 & 1.33 \\
\hline
\end{tabular}

Table B-1. Target Compositions (Oxide Basis) of SOA Sludges 


\section{APPENDIX C - ANALYSES OF THE SOA MRF GLASSES AND SOA SMRF FEEDS}




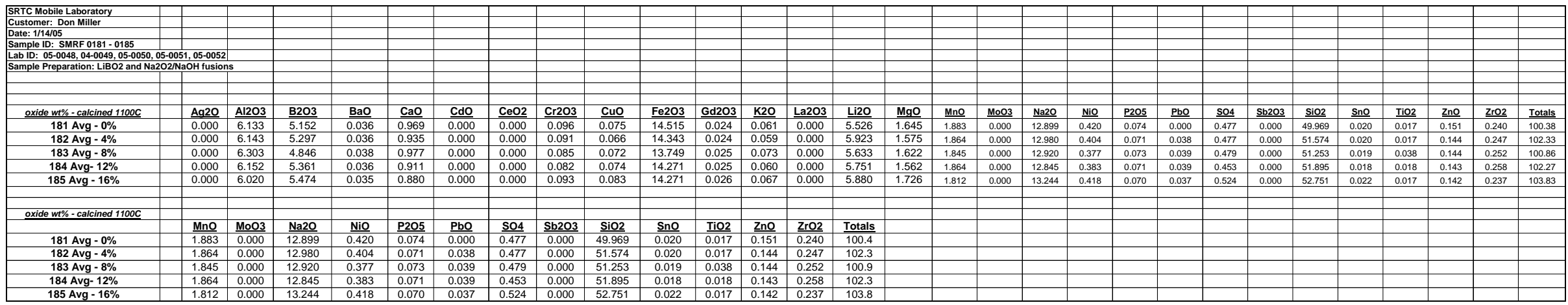

Table C-1. MRF SOA Glass Analytical Results

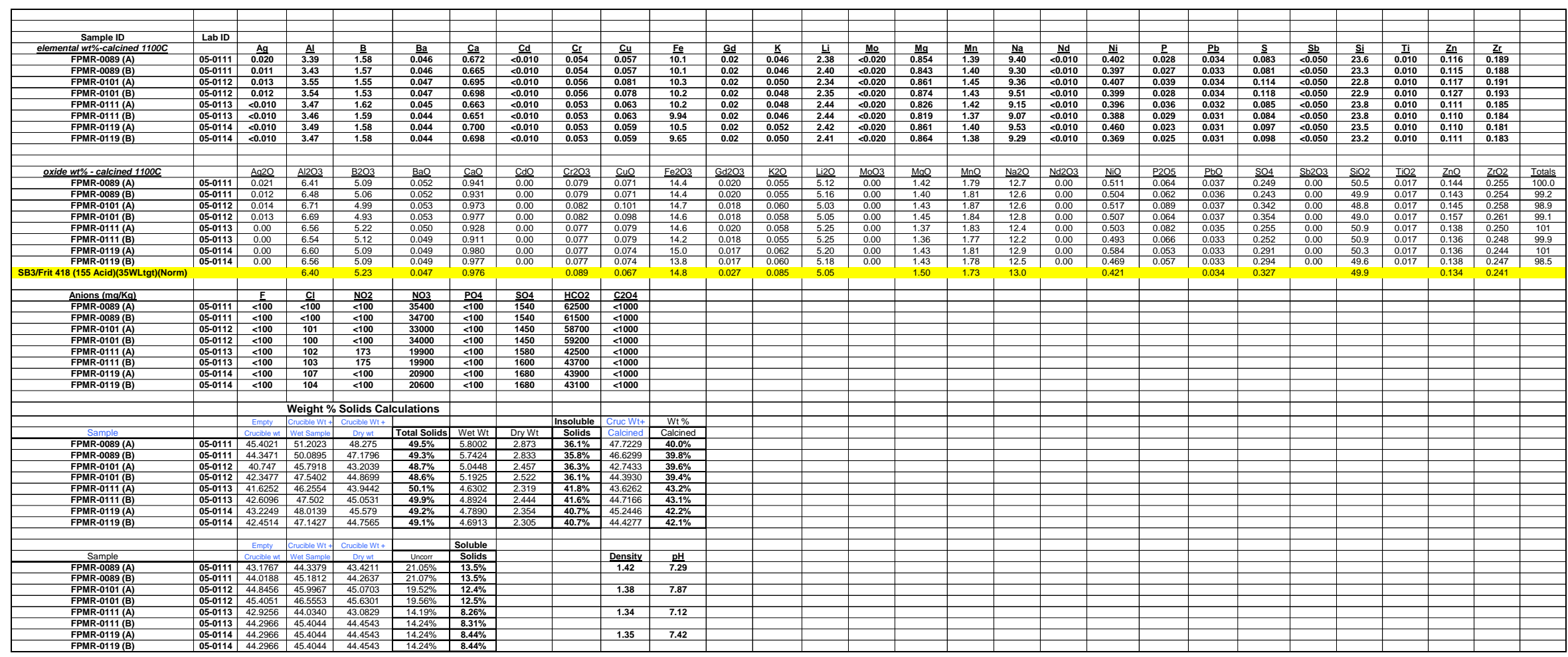

Table C-2. SMRF SOA Feed Analytical Results (NOTE: Samples FPMR-0089/0101 and 0111/0119 are from 4\% and 12\% SOA feeds respectively) 


\section{APPENDIX D - CROSS-SECTIONS OF MRF SOA TEST BEAKERS}




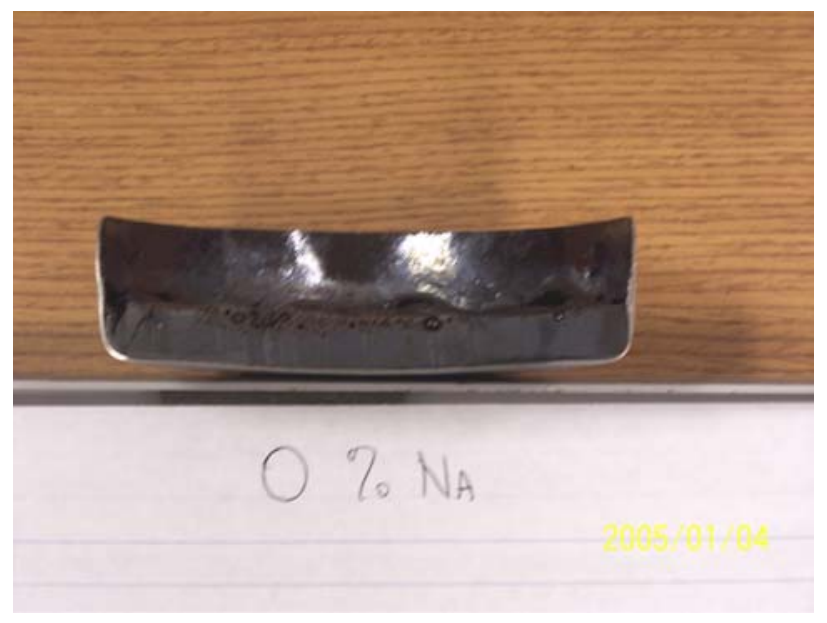

Figure D-1. Cross-Section of 0\% MRF SOA Beaker

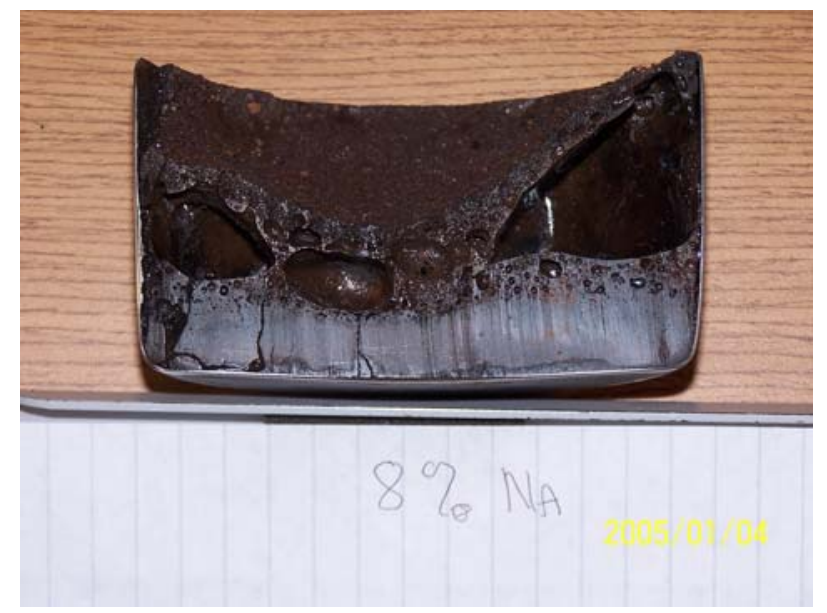

Figure D-2. Cross-Section of 8\% MRF SOA Beaker

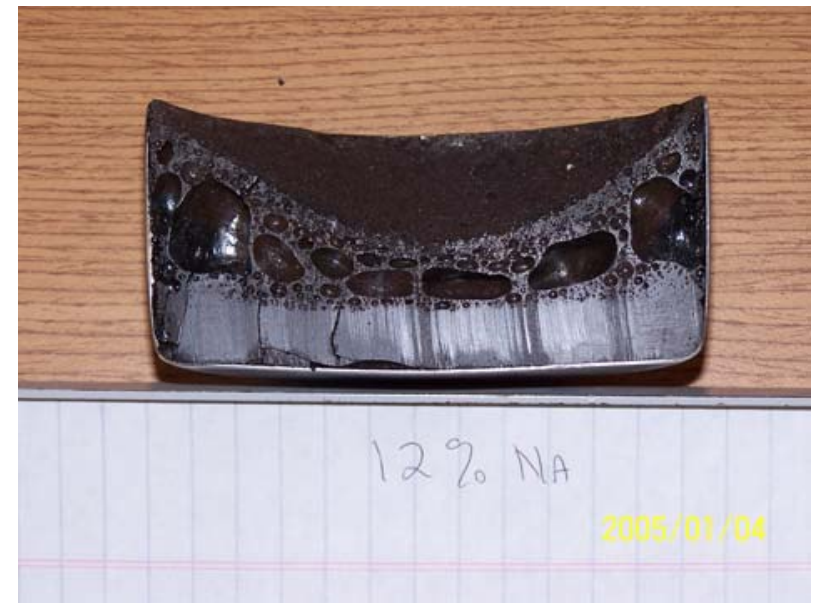

Figure D-3. Cross-Section of 12\% MRF SOA Beaker 
This page intentionally left blank. 


\section{Distribution:}

J. E. Marra, 773-A

E. W. Holtzscheiter, 773-A

D. A. Crowley, 999-W

S. L. Marra, 999-W

T. B. Calloway, 999-W

N. E. Bibler, 773-A

C. M. Jantzen, 773-A

J. R. Harbour, 773-42A

C. A. Langton, 773-43A

G. C. Wicks, 773-A

T. H. Lorier, 999-W

M. E. Smith, 773-42A

D. H. Miller, 786-1A

T. M. Jones, 999-W

D. K. Peeler, 999-W

C. C. Herman, 773-42A

M. E. Stone, 999-W

M. A. Baich, 999-W

T. L. Fellinger, 773-A

A. S. Choi, 773-42A

M. S. Miller, 704-S

A. B. Barnes, 704-30S

J. E. Occhipinti, 704-S

R. M. Hoeppel, 704-27S

J. F. Iaukea, 704-30S

D. C. Iverson, 704-30S

R. J. O’Driscoll, 704-30S

J. W. Ray, 704-S

J. F. Sproull, 704-30S

F. A. Washburn, 704-27S 